\title{
Reduced Neurogenesis after Neonatal Seizures
}

\author{
Bridget K. McCabe, Diosely C. Silveira, Maria Roberta Cilio, Byung Ho Cha, Xianzeng Liu, Yoshimi Sogawa, \\ and Gregory L. Holmes
}

Department of Neurology, Harvard Medical School, Children's Hospital, Boston, Massachusetts 02115

\begin{abstract}
Although neonatal seizures are quite common, there is controversy regarding their consequences. Despite considerable evidence that seizures may cause less cell loss in young animals compared with mature animals, there are nonetheless clear indications that seizures may have other potentially deleterious effects. Because it is known that seizures in the mature brain can increase neurogenesis in the hippocampus, we studied the extent of neurogenesis in the granule cell layer of the dentate gyrus over multiple time points after a series of 25 flurothylinduced seizures administered between postnatal day 0 (P0) and P4. Rats with neonatal seizures had a significant reduction in the number of the thymidine analog 5-bromo-2'deoxyuridine-5'-monophosphate- (BrdU) labeled cells in the dentate gyrus and hilus compared with the control groups when the animals were killed either 36 hr or 2 weeks after the BrdU
\end{abstract}

injections. The reduction in BrdU-labeled cells continued for $6 \mathrm{~d}$ after the last seizure. BrdU-labeled cells primarily colocalized with the neuronal marker neuron-specific nuclear protein and rarely colocalized with the glial cell marker glial fibrillary acidic protein, providing evidence that a very large percentage of the newly formed cells were neurons. Immature rats subjected to a single seizure did not differ from controls in number of BrdUlabeled cells. In comparison, adult rats undergoing a series of 25 flurothyl-induced seizures had a significant increase in neurogenesis compared with controls. This study indicates that, after recurrent seizures in the neonatal rat, there is a reduction in newly born granule cells.

Key words: neurogenesis; seizures; bromodeoxyuridine; hippocampus; dentate gyrus; epilepsy; neuron-specific nuclear protein; glial fibrillary acidic protein
Seizures occur more frequently in the neonatal period than at any other time in life (Lanska et al., 1995; Mizrahi et al., 1997). In addition to the increased risk for epilepsy in children, seizures during early development may be more detrimental than when occurring during adulthood (Bergman et al., 1983; Painter et al., 1986).

Animal studies have demonstrated that the pathophysiological consequences of seizures in the developing brain differ from those of the mature brain. In the adult animal, status epilepticus causes neuronal loss in the hippocampus (Meldrum et al., 1973; Nadler et al., 1978; Nadler, 1981), leads to aberrant growth (sprouting) of granule cell axons in the supragranular zone of the dentate gyrus (Represa et al., 1987; Okazaki et al., 1995) and pyramidal cell region of CA3 (Represa et al., 1987), and results in long-term deficits in learning, memory, and behavior (Stafstrom et al., 1993). However, studies have demonstrated that a single prolonged seizure in an immature rat results in no discernible cell loss (Sperber et al., 1991; Stafstrom et al., 1992), sprouting (Sperber et al., 1991), or impairment of learning, memory, and behavior (Stafstrom et al., 1993).

Despite the lack of cell loss, immature animals are not invulnerable to seizure-induced injury (Sankar et al., 1998, 2000; Toth

\footnotetext{
Received June 14, 2000; revised Dec. 22, 2000; accepted Jan. 4, 2001.

This research was supported by the Emily P. Rogers Research Fund, Mental Retardation Research Center Grant HD18655-19 from the National Institutes of Health, National Institute of Neurological Disorders and Stroke Grant NS27984 to G.L.H, and a fellowship to M.R.C. from the Eugenio Litta Foundation (Geneva, Switzerland). We thank Sanjay S. Magavi for assistance with the fluorescence procedures, Scott Pomeroy for instructions on the confocal microscope, and Francis Jensen for her advice regarding study design.

Correspondence should be addressed to Dr. Gregory L. Holmes, Clinical Neurophysiology Laboratory, Hunnewell 2, Children's Hospital, 300 Longwood Avenue, Boston, MA 02115. E-mail: holmesg@a1.tch.harvard.edu.

Copyright (C) 2001 Society for Neuroscience 0270-6474/01/212094-10\$15.00/0
}

et al., 1998; Chen et al., 1999). There is increasing evidence that seizures, particularly recurrent ones, can alter the brain through mechanisms other than cell death (Wasterlain and Plum, 1973; Wasterlain, 1978; Holmes et al., 1998, 1999; Liu et al., 1999). Recurrent or prolonged seizures during the neonatal period have been shown to reduce brain cell number (Wasterlain and Plum, 1973; Wasterlain, 1976b). Recurrent neonatal seizures can result in synaptic reorganization with aberrant growth of dentate granule cell axons into the inner molecular layer of the granule cell layer and the intrapyramidal and stratum oriens of the CA3 subfield (Holmes et al., 1998; Liu et al., 1999). Recurrent seizures during the first week of life also result in impairment of learning and memory and a lower seizure threshold when rats are studied as adults (Holmes et al., 1998). These morphological, behavioral, and physiological changes occur in the absence of any discernible cell loss.

Recently, a number of investigators have reported an increase in dentate granule cell neurogenesis after seizures in adult animals (Bengzon et al., 1997; Parent et al., 1997, 1998; Scott et al., 1998; Gray and Sundstrom, 1998). This finding raises interesting questions about the pathophysiology of seizure-induced brain damage. Increased neurogenesis after seizure-induced cell loss may result in new and aberrant neuronal circuits. The effects of seizures on granule cell proliferation in the newborn rat, at a time of intense granule cell neurogenesis, remain primarily unknown. Wasterlain and colleagues (Wasterlain and Plum, 1973; Wasterlain, 1976b, 1978; Suga and Wasterlain, 1980) demonstrated a reduction of cell number with seizures during early development, suggesting that neonatal seizures may result in a reduction rather than an increase in neurogenesis. Also, Suga and Wasterlain (1980) found a reduction of mitosis in the cerebellar vermis of rat pups who underwent bicuculline-induced status epilepticus. Con- 
versely, in a previous study from our laboratory (Holmes et al., 1998), we found an increase in neurogenesis after a series of neonatal seizures. However, in that study, neurogenesis was assessed at only one time point. The goal of this study was to assess the effect of recurrent brief tonic seizures during the neonatal period on neurogenesis in the hippocampus. We found that recurrent seizures resulted in a decrease in cellular proliferation in the hours and days after the seizures. This contrasted to our findings in a parallel study in adult rats in which there was an increase in neurogenesis after a similar series of seizures.

\section{MATERIALS AND METHODS}

Sprague Dawley rats were used in all experiments and were treated in accordance with the guidelines set by the National Institutes of Health for the humane treatment of animals. Attempts were made to minimize the number of animals used. Animals had access to food and water ad libitum; they were housed with their litter until weaning at postnatal day 21 (P21), after which they were grouped in plastic cages under diurnal lighting conditions with $12 \mathrm{hr}$ on and $12 \mathrm{hr}$ off. In all experiments, littermates were randomly assigned to either the experimental or control groups. Experimental and control animals remained together with the dam until weaning.

Sixteen rats were used for a pilot study of 5-bromo-2'-deoxyuridine$5^{\prime}$-monophosphate (BrdU) dosage and 126 immature rats [experimental (exp.), $n=63$; control (con.), $n=63$ ] were used for the time course study of neurogenesis in immature rats. Twelve rats (exp., $n=6$; con., $n=6$ ) were used to determine the consequence of a single seizure on neurogenesis. Eight (exp., $n=4$; con., $n=4$ ) adult, male rats were used to compare neurogenesis in response to recurrent seizures in adult and immature animals.

Seizure induction. The volatile agent flurothyl (bis-2,2,2-triflurothyl ether) (Aldrich, Milwaukee, WI), a potent and rapidly acting CNS stimulant that produces seizures within minutes of exposure, was used to induce seizures (Neill et al., 1996; Holmes et al., 1998). Rats were placed in a small cylinder plastic container, and liquid flurothyl was delivered through a plastic syringe and dripped slowly onto filter paper in the center of the container, where the agent evaporates. Experimental rats $(n=85)$ were exposed to flurothyl until tonic extension of both the forelimbs and hindlimbs was observed. A total of 25 seizures were induced in the experimental rats starting at P0 (the day of birth) and ending at P4. Each rat received five seizures per day with a minimum of $2 \mathrm{hr}$ between seizures. Between trials, the chamber was flushed with room air and cleaned. Control rats $(n=85)$ were placed in the chamber for equivalent periods of time as the experimental rats but were not exposed to flurothyl. In the single seizure experiment, experimental animals $(n=14)$ had a single seizure induced at P4, whereas control rats $(n=14)$ were placed in the chamber but not exposed to flurothyl.

In the adult study, a total of 25 seizures were induced in the experimental group $(n=4)$ with each rat receiving two to three flurothyl seizures per day from P60 to P69 with a minimum of $3 \mathrm{hr}$ between seizures. Control rats $(n=4)$ were placed in the chamber for equivalent periods of time as the experimental rats but were not exposed to flurothyl. Because previous studies using this method of seizure induction in adult rats caused a mortality rate of $>20 \%$, we elected to reduce the number of seizures per day for the adult animal from five to two to three per day.

BrdU labeling. BrdU is a thymidine analog that is incorporated into the DNA during the S phase of the cell cycle (del Rio and Soriano, 1989; Soriano and del Rio, 1991). Each injection of BrdU labels only those proliferating cells that are in the DNA-synthetic phase of the cell cycle (S phase). Because BrdU is available for $\sim 30$ min (Packard et al., 1973), only a proportion of dividing cells will be labeled by a single injection (Nowakowski et al., 1989). In a pilot study, we compared cell counts of BrdU-labeled neurons in rats $(n=8)$ receiving a single $100 \mathrm{mg}$ intraperitoneal injection of BrdU versus rats receiving four $50 \mathrm{mg}$ injections administered every $6 \mathrm{hr}(n=8)$ in both rats with recurrent flurothyl seizures and controls. BrdU administration began after the 25th seizure or sham seizure, and the animals were killed $36 \mathrm{hr}$ later. Although cell counts were higher in the animals with four separate injections, these results did not reach statistical significance [con., $100 \mathrm{mg} / \mathrm{kg}, 2807 \pm 141$; $50 \mathrm{mg} / \mathrm{kg}$ for four times $(\times 4), 3484 \pm 318.6 ; t=1.331 ; p=0.198$; exp., $100 \mathrm{mg} / \mathrm{kg}, 2758 \pm 154 ; 50 \mathrm{mg} / \mathrm{kg} \times 4,2761 \pm 454 ; t=0.238 ; p=0.814]$. There was no indication from this experiment, or the work of others
(Nowakowski et al., 1989; Holmes et al., 1998), that the dose of BrdU used in the neonatal rat has cytotoxic effects. The modest increase in labeled cells when $50 \mathrm{mg} / \mathrm{kg}$ of BrdU was administered four times over a $24 \mathrm{hr}$ period was probably secondary to an increased likelihood that a greater number of cells in the S phase would be exposed to the BrdU. There was a high density of labeled cells in animals killed $36 \mathrm{hr}$ after injection of BrdU. Because of the high density of BrdU-labeled cells in the $50 \mathrm{mg} / \mathrm{kg} \times 4$ group, counting, either manually or with computer assistance, was difficult. Additionally, intraperitoneal injections are stressful and could result in introducing another confounding variable into the study. For that reason, single injections of $100 \mathrm{mg} / \mathrm{kg} \mathrm{BrdU}$ were used throughout the study.

Rats were given a single injection of BrdU, dissolved in 0.1 M PBS (Sigma, St. Louis, MO), to label mitotically active cells. For the time course study in the immature rats, animals received BrdU immediately after ( $0 \mathrm{hr}$ ) or $1,2,3,4,6$, or $12 \mathrm{~d}$ after the final seizure (25th seizure) in the experimental group ( $n=6$ animals per time point) or sham seizure treatment ( $n=6$ animals per time point) in the control group. The animals were killed $36 \mathrm{hr}$ after BrdU administration. By examining the brains at $36 \mathrm{hr}$, we were able to measure neurogenesis at a time when there were likely to be few subsequent cell divisions. To determine the final position and cell type of the newly born cells, a second group of animals received BrdU at the same time points and were killed 2 weeks after injection $(n=3$ at each time point for both the controls and recurrent seizure groups).

To determine the number of seizures required to induce changes in neurogenesis after neonatal seizures, we administered BrdU to rats $1 \mathrm{hr}$ after $5,10,15$, or 20 seizures $(n=4$; sham seizure controls, $n=4$ at each time point).

For the single seizure study, BrdU (100 mg/kg) was administered either $24(n=12)$ or $48(n=8)$ hr after a single flurothyl-induced or sham seizure induced at P4. The animals were killed along with an identical number of controls either $36 \mathrm{hr}$ or 2 weeks latter (48 hr time point only).

To verify findings reported previously (Holmes et al., 1998) demonstrating an increase in neurogenesis when BrdU was administered before a 25th seizure, we also administered BrdU after the 24th and before the final (25th) seizure at P4 $(n=6)$ and then compared the number of BrdU-labeled cells at $36 \mathrm{hr}$ with an equal number of controls $(n=6)$. To determine whether the timing of $\mathrm{BrdU}$ was a determining factor in measuring neurogenesis, we also gave BrdU immediately before a sham 25 th seizure to rats who had 24 previous seizures $(n=3$; controls without seizures, $n=3$ ).

For the adult study, male adult rats were given BrdU immediately after or $3 \mathrm{~d}$ after the final (25th) seizure in the experimental group or at the equivalent time point in the control group. The adult animals were killed 2 weeks after the BrdU injections.

Blood gas measurements. To assess the degree of hypoxia, hypercapnia, and acidosis during the flurothyl-induced seizures, we did blood gases on both rat pups and adult rats at baseline, during the tonic phase of the seizure, and $5 \mathrm{~min}$ after the beginning of the tonic seizure at a time the animal was in a postictal state. Arterial blood was obtained from the rat pups (P4 or $\mathrm{P} 5 ; n=20)$ through a 25 gauge needle via direct cardiac puncture into the left ventricle. Only a single blood gas was obtained for each pup. In the adult rats $(n=4)$, a right femoral artery 25 gauge catheter was placed under general anesthesia. Once the animal was fully recovered, baseline gases were obtained at the same points as the rat pups.

Tissue fixation and immunohistochemistry. After deep anesthesia with sodium pentobarbital $(60 \mathrm{mg} / \mathrm{kg}$ body weight $)$, the animals were transcardially perfused as follows: normal $(0.9 \%)$ saline for $2 \mathrm{~min}$ and then $4 \%$ paraformaldehyde (PFA) in $0.1 \mathrm{M}$ phosphate buffer, $\mathrm{pH} 7.0$, for 5-10 min (adults for 20-30 min). After post-fixation in situ in PFA for $24 \mathrm{hr}$, the brains were placed in a solution of $20 \%$ sucrose $(\mathrm{w} / \mathrm{v})$ in $0.1 \mathrm{M}$ PBS and $0.2 \%$ sodium azide $(\mathrm{w} / \mathrm{v})$ until the brains sank to the bottom of the chamber. Coronal sections through the entire extent of the hippocampus were cut at $50 \mu \mathrm{M}$ (40 $\mu \mathrm{M}$ for the adults) with a freezing microtome, and sections were stored in PBS with $0.2 \%$ sodium azide until processed.

Brains from both age-matched control and experimental animals were always processed together. Immunohistochemistry was performed on free-floating sections throughout the entire extent of the hippocampus as described by del Rio and Soriano (1989) and Parent et al. (1997). For the BrdU immunostaining, tissue permeabilization was achieved with $1 \mathrm{hr}$ incubation in $0.5 \%$ PBST ( $0.1 \mathrm{M}$ PBS and $0.5 \%$ Triton X-100). The DNA was denatured with $2 \mathrm{~N} \mathrm{HCl}$ at $45^{\circ} \mathrm{C}$ for $20 \mathrm{~min}$ ( $30 \mathrm{~min}$ for adult rats). The $\mathrm{HCl}$ was neutralized by placing the sections in $0.1 \mathrm{~m}$ borate buffer, 
$\mathrm{pH} 8.5$, at room temperature for $20 \mathrm{~min}$. The sections were rinsed three times with PBS and treated with an endogenous peroxidase inhibition solution of $0.6 \% \mathrm{H}_{2} \mathrm{O}_{2}(\mathrm{v} / \mathrm{v}), 0.9 \%$ saline (w/v), and $50 \%$ ethanol (v/v) for $45 \mathrm{~min}$. The sections were rinsed again with PBS three times and placed in PBSTG [0.5\% porcine gelatin (w/v) in $0.3 \%$ PBST $(0.1 \mathrm{M}$ PBS and $0.3 \%$ Triton $\mathrm{X}-100$ ) and $0.2 \%$ sodium azide] for $1 \mathrm{hr}$. Tissue sections were incubated with a primary antibody (diluted in PBSTG) to BrdU (mouse monoclonal, 1:1000; Boehringer Mannheim, Indianapolis, IN) overnight at room temperature. After rinsing with PBS five times, the sections were incubated with a biotinylated secondary antibody diluted with PBSTG (affinity-purified sheep anti-mouse IgG, 1:1500; Boehringer Mannheim) for $2 \mathrm{hr}$, washed with PBS five times, and then incubated in avidin-biotin-peroxidase complex (Vectastain Elite ABC; Vector Laboratories, Burlingame, CA) for $1 \mathrm{hr}$. After four rinses in PBS and two rinses in Tris (50 mm Tris, $\mathrm{pH} 7.6$ ), peroxidase activity was visualized as follows: sections were preincubated in $0.05 \%$ 3,3'-diaminobenzidinetetrahydrochloride (w/v) (DAB) (Sigma) in 50 mm Tris, pH 7.6, containing $0.4 \%$ ammonium nickel sulfate for $8 \mathrm{~min}$, and then $30 \mu \mathrm{l}$ of $0.3 \%$ $\mathrm{H}_{2} \mathrm{O}_{2}(\mathrm{v} / \mathrm{v})$ was added to $5 \mathrm{ml}$ of the preincubation DAB solution containing the sections. After 1-2 min of additional incubation with the $\mathrm{H}_{2} \mathrm{O}_{2}$, the sections were rinsed in $50 \mathrm{~mm}$ Tris, $\mathrm{pH}$ 7.6, four times and then placed on gelatin slides, dehydrated in alcohol, cleared in xylene, and coverslipped. Sections of controls were always stained simultaneously and with the exact same procedure as the flurothyl-treated animals. In addition, immunohistochemical controls, in which the primary antibody was omitted, were done for all experiments.

Double-labeled immunofluorescence. Double-labeled immunofluorescence was conducted in a similar manner to the method described by Parent et al. (1997). Free-floating sections were placed in $2 \mathrm{~N} \mathrm{HCl}$ at room temperature for $30 \mathrm{~min}$ and then transferred to $0.1 \mathrm{M}$ borate buffer, $\mathrm{pH} 8.5$, for $20 \mathrm{~min}$ at room temperature. After rinsing with PBS two times, the sections were placed in a bovine serum albumin (BSA) blocking solution $(0.3 \%$ BSA and $0.3 \%$ Triton X-100) for $1 \mathrm{hr}$ and then incubated overnight at room temperature with primary antibody to neuronal nuclei [neuron-specific nuclear protein (NeuN), mouse monoclonal, 1:200; Chemicon, Temecula, CA] or to glial fibrillary acidic protein (GFAP) (rabbit monoclonal, 1:200; Sigma), which was diluted with the BSA blocking solution. After washing in PBS five times, the sections were incubated for $2 \mathrm{hr}$ at room temperature with a goat anti-mouse or anti-rabbit secondary antibody conjugated to Alexa 546 (diluted with the BSA blocking solution 1:500; Molecular Probes, Eugene, OR). The sections were washed in PBS five times and then incubated overnight at room temperature with a primary antibody to BrdU (rat monoclonal, 1:100 dilution; Accurate Chemicals, Westbury, NY), which was diluted in the BSA blocking solution. The sections were washed in $1 \%$ PBST (0.1 M PBS and $1 \%$ Triton X-100) three times and then incubated for $2 \mathrm{hr}$ at room temperature with a goat anti-rat secondary antibody conjugated to Alexa 488 (diluted with the BSA blocking solution 1:250; Molecular Probes). The sections were washed several times and placed on gelatin-coated slides and coverslipped with ProLong anti-fade medium (Molecular Probes). The fluorescence was visualized with a Nikon (Tokyo, Japan) Microphot-FXA microscope.

Quantification and statistical analysis. For all BrdU labeling experiments, mounted sections spaced at least $150 \mu \mathrm{M}$ apart were used. As described by Parent et al. (1997), six to eight sections per animal (12-16 hippocampi) divided between the anterior, middle, and posterior portions of the dorsal hippocampus were analyzed in an area encompassing the entire granule cell layer (superior and inferior blades) and extending approximately one to two cell layers width into the hilus. Based on anatomical landmarks, equivalent sections from control and experimental animals were chosen and coded by one of the authors. The number of BrdU-labeled cells per area of dentate granule cell layer and the number of BrdU-labeled cells per area of hilus (excluding the one to two cell layers width directly adjacent to the granule cell layer of the dentate gyrus) were then counted either manually or through computer assistance by a blinded examiner. Animals killed $36 \mathrm{hr}$ after BrdU administration had well delineated, dense, nuclear BrdU staining that allowed computer-assisted counting. In animals killed 2 weeks after BrdU, there was a combination of both densely stained nuclei and more diffuse, speckled patterns. Because of the light staining of some of these cells, we found that more accurate counting could be achieved through manual counting.

For computer-assisted counting, images were magnified $100 \times$, and images were captured digitally to a monitor using an image analysis system (Image Pro; Media Cybergenics, Silver Spring, MD). Light inten- sity and filter settings were maintained at a constant level for all specimens. Once an image was captured to screen, it was then converted to a gray scale. BrdU-labeled cells, which stained darkly, were then counted automatically. With both manual and computer-assisted counting, cells were systematically counted from the edge of the inferior blade of the granule cell layer to the crest and then along the superior blade to the crest. Hilar cell counts were then made after the same procedures. To determine accuracy of the computer-assisted device, every 10th specimen was also counted manually by an investigator blinded to the computer results. In all specimens counted both automatically and by hand, there was an excellent agreement $(<5 \%$ difference).

Area measurements of both the dentate granule cell layer and hilus were also made from each slide used for the cell counts. At $40 \times$ magnification, images were captured digitally to a monitor using the same image analysis system as described previously (Holmes et al., 1999), and the granule cell layer of the dentate gyrus and hilus were outlined and the area was calculated.

The experimental group mean value (number of BrdU-labeled cells per area) was compared with the control group mean value with the Student's $t$ test (StatView software; SAS Institute Inc., Cary, NC). For quantifying double-labeled immunofluorescence, the number of BrdUpositive cells alone and double-labeled with either NeuN or GFAP were manually counted by an examiner blinded to study group. To assess the scoring by the blinded examiner, 30 randomly chosen cells exhibiting BrdU-labeled nuclei, of which a random number were double-labeled with NeuN, were scored as double-labeled or not by the examiner and an independent observer. An inter-rater reliability of $90 \%$ was found for assessing BrdU and NeuN colocalization. The same inter-rater assessment was done for 30 cells for the double-labeling of BrdU and GFAP, and the inter-rater reliability was again 90\%. To further assess the reliability of counting, counting of double-labeled cells was also performed using a confocal imaging system equipped with a krypton-argon laser and Nikon Diaphot microscope.

\section{RESULTS}

The seizures were quite stereotyped. After exposure to the flurothyl, the neonatal rats initially became quite agitated, with head bobbing or turning from side to side. This was followed by attempts at running, squealing, and loss of posture. The rats would then invariably develop tonic posturing with both the forelimbs and hindlimbs stiffly extended. Mild perioral cyanosis, urinary and fecal incontinence, and salivation was often noted. Rats were removed from the chamber as soon as the tonic phase began and allowed to recover in room air. Typically, the rats returned to baseline behavior within $10-15 \mathrm{~min}$.

In the adult rats exposed to flurothyl, the first behavioral change consisted of agitation followed by myoclonic or clonic activity of the forelimbs followed by running, loss of posture, and eventually tonic posturing with both the forelimbs and hindlimbs stiffly extended. Mild perioral cyanosis, urinary and fecal incontinence, and salivation was frequently noted. Rats returned to baseline behavior within 30-45 min.

In both the pups and adult rats, hypoxia was observed during the tonic phase of the seizures (Fig. $1 A, B$ ). There was not a significant difference in the adult and immature rats in $\mathrm{pO}_{2}(t=$ $0.8028 ; p=0.458), \mathrm{pCO}_{2}$ levels $(t=1.659 ; p=0.1580)$, or oxygen saturations $(t=0.7669 ; p=0.4778)$ during the tonic phase of the seizure. During the tonic phase of the seizure, adult animals had a significantly greater degree of acidosis than the immature rats $(t=2.847 ; p=0.0293)$. In both the adult and rat pups, the $\mathrm{pO}_{2}$, $\mathrm{O}_{2}$ saturations, $\mathrm{pCO}_{2}$, and $\mathrm{pH}$ returned to baseline $5 \mathrm{~min}$ after the onset of the seizure with no significant differences between the adult and immature rats in any of these measures.

Both age groups tolerated the flurothyl seizures well. There was one death among the rats that received flurothyl in the neonatal period and one in the adult group. None of the controls died. 


$$
\begin{aligned}
& \square \text { Baseline } \\
& \square \text { Tonic } \\
& -5 \text { min. }
\end{aligned}
$$

$\mathbf{A}$
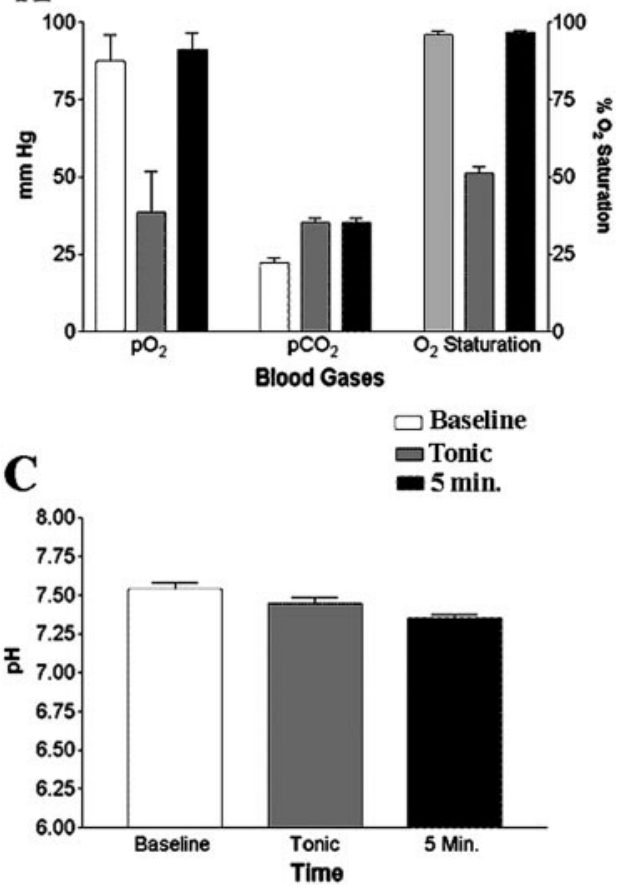

$\square$ Baseline

$\square$ Tonic

$=5$ min.

B
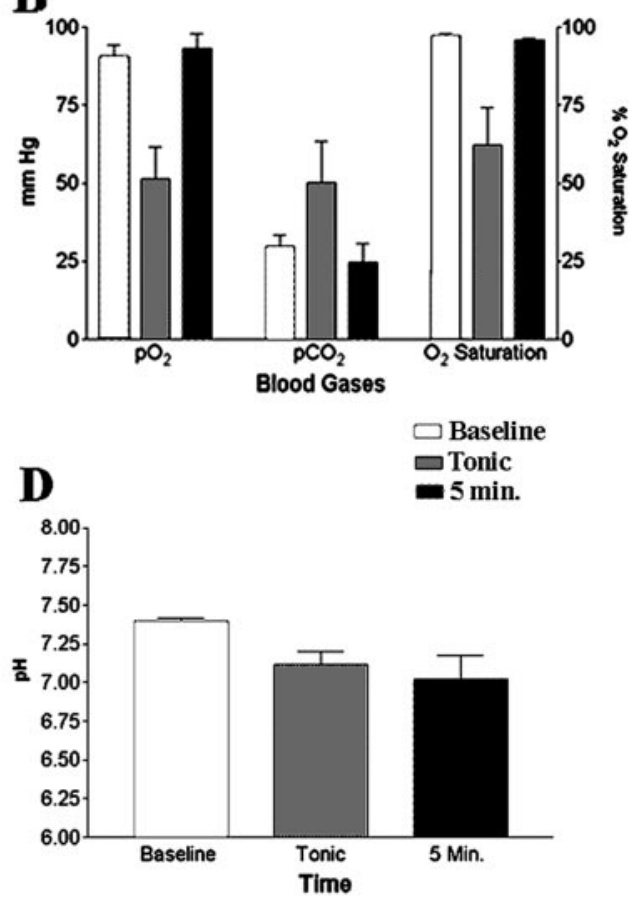

Figure 1. Comparison of $\mathrm{pO}_{2}, \mathrm{pCO}_{2}$, and $\mathrm{O}_{2}$ saturation $(A, B)$ and $\mathrm{pH}(C, D)$ in $\mathrm{P} 4$ or $\mathrm{P} 5$ rats $(A, C)$ and adult rats $(B$, $D)$. All analyses were done in room air at baseline, $1 \mathrm{~min}$ after onset of the tonic seizures, and $5 \mathrm{~min}$ after the onset of the tonic seizure. No statistical differences were found in $\mathrm{pO}_{2}, \mathrm{pCO}_{2}$, and $\mathrm{O}_{2}$ saturations between the rat pups and adult rats at any of the time points. During the tonic phase of the seizure, adult animals had a significantly greater degree of acidosis than the immature rats.
Recurrent flurothyl-induced seizures in the first $5 \mathrm{~d}$ of life reduce the number of differentiated cells whose progenitors were mitotically active shortly after the seizures in the dentate gyrus and in the hilus

In concordance with previous reports (Schlessinger et al., 1975; Altman and Bayer, 1990), the number of mitotically active parent cells and their offspring that survived until the time of being killed at either $36 \mathrm{hr}$ or 2 weeks was greatest in the younger animals (Figs. 2, 3, 4), whether or not the animals were induced with seizures. The highest number of BrdU-labeled cells occurred in the youngest animals injected at P4 (after the 25th seizure) and decreased until the last day the animals received BrdU.

When we examined the effect of seizures compared with ageappropriate controls, we noted a significant decrease in the num- ber of BrdU-labeled cells in the dentate granule cell layer of the dentate gyrus either 36 hr (Figs. 2, 4) or 2 weeks (Fig. 3) after BrdU administration in the flurothyl-treated group compared with the matched controls. In animals that received BrdU shortly after the 25th seizure and 1, 2, 3, and $4 \mathrm{~d}$ later, there was a decrease in BrdU-labeled cells in the experimental group. However, when BrdU was administered 6 and $12 \mathrm{~d}$ after the last seizure, no difference in number of BrdU-labeled cells was seen between the control and the seizure groups. Although there were fewer BrdU-labeled cells in animals killed 2 weeks after injection, the magnitude of the differences between the controls and animals with recurrent seizures was similar. In animals killed 2 weeks after BrdU, there was an increased number of BrdU-
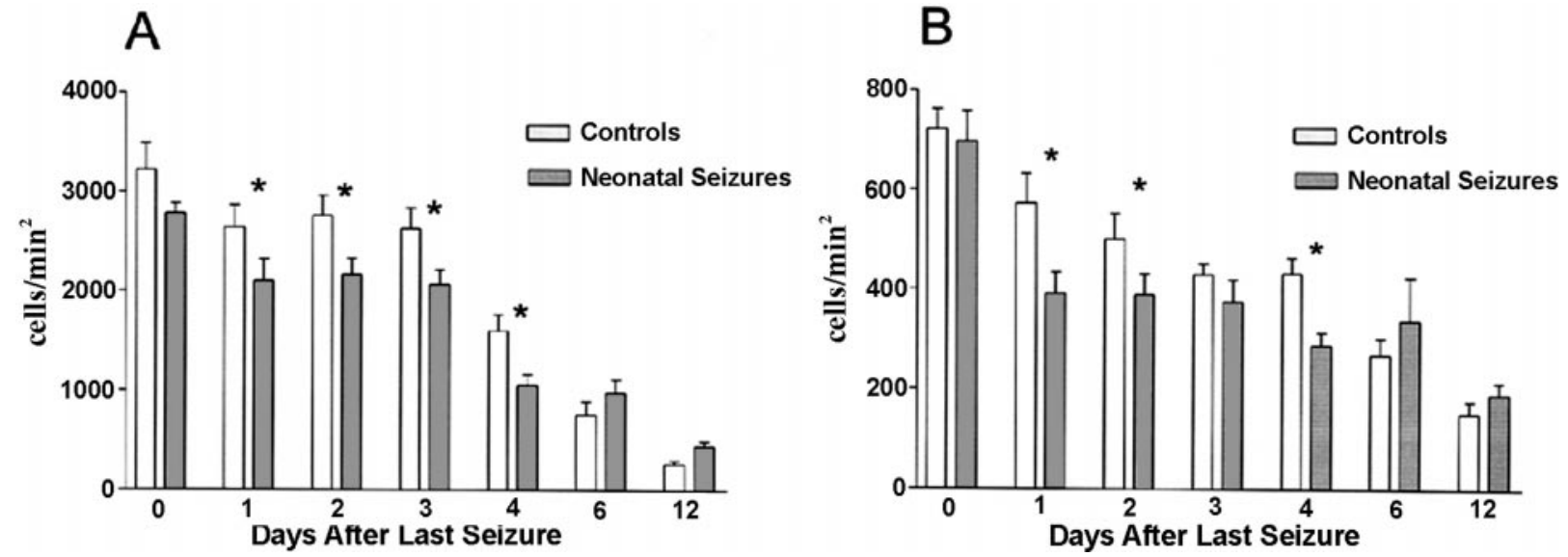

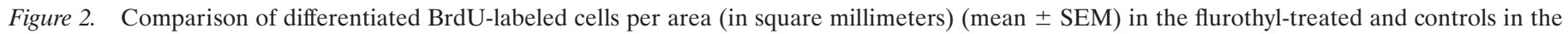

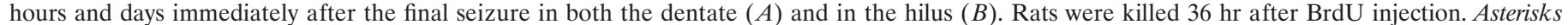

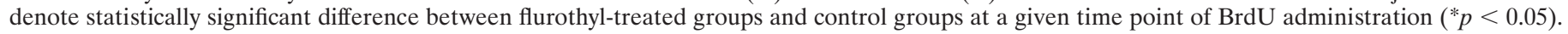



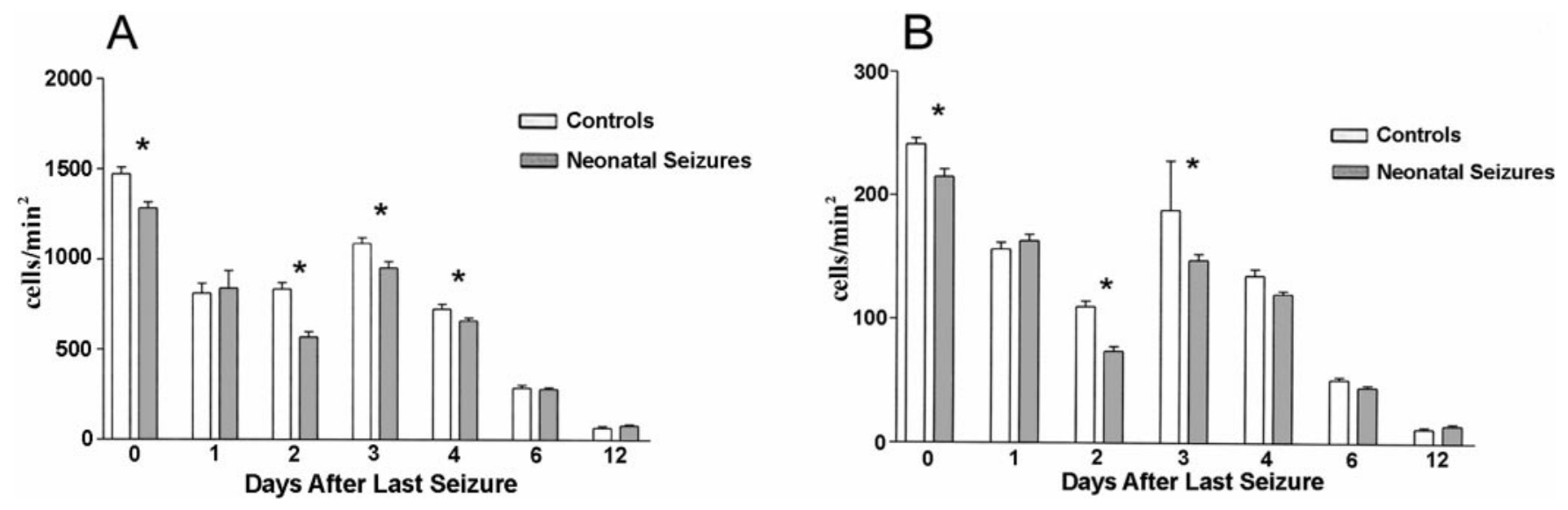

Figure 3. Comparison of differentiated BrdU-labeled cells per area (in square millimeters) (mean \pm SEM) in the flurothyl-treated and controls in the hours and days immediately after the final seizure in both the dentate $(A)$ and in the hilus $(B)$ in rats killed 2 weeks after BrdU injection. Asterisks denote statistically significant difference between flurothyl-treated groups and control groups at a given time point of BrdU administration $\left({ }^{*} p<0.05\right)$.

labeled cells in both the controls and flurothyl-treated animals at the $3 \mathrm{~d}$ time point. Because the number of BrdU-labeled cells exceeded those at the 2 and $4 \mathrm{~d}$ time points, we repeated the analysis at this time point in additional animals. No significant differences were found (data not shown). The reason for this increase in cells at day 3 in animals killed at 2 weeks is not clear. Figure 4 provides examples of the BrdU-labeled cells at various time points. Hilar cell counts followed a similar pattern. Sections from the anterior, middle, and posterior regions of the hippocampus did not show any quantitative differences in amount of staining (number of labeled cells per area) in either the controls or flurothyl-treated rats. This finding of a decreased number of differentiated cells after seizure induction contrasts to the previous reports of increased proliferation of neurons after seizure induction in the mature adult animal (Bengzon et al., 1997; Parent et al., 1997; Scott et al., 1998).

There were differences in both the pattern of staining and distribution of cells at the two different time points the animals were killed. At high power, BrdU-labeled cells from rats killed 36 hr after injection typically had dense and homogeneous staining of the round nuclei. BrdU-labeled cells from animals killed 2 weeks after had a mixture of round densely labeled nuclei, as well as those that had a more variable, often speckled (soccer ball) pattern, as described by others (Parent et al., 1997). Rats killed 36 hr after BrdU injection had a preponderance of cells confined to the hilar border of the granule cell layer of the dentate gyrus, whereas rats killed 2 weeks after the injection revealed positively stained nuclei evenly throughout the cell widths of the dentate gyrus, and sporadically throughout the hilus.

To determine the identity of the BrdU-labeled cells, sections from both control and flurothyl-treated animals that received BrdU shortly after the 25 th seizure and 3 and $6 \mathrm{~d}$ after the final seizure $(n=25)$ underwent fluorescence double-labeled immunohistochemistry. Fluorescence microscopic analysis demonstrated colocalization of BrdU-labeled nuclei within cells stained with a differentiated neuron-specific marker, NeuN (Fig. 5), and was verified by a second observer with $90 \%$ agreement. In addition, these findings were verified using confocal microscopy. Nearly all BrdU-labeled nuclei in the dentate granule cell layer of the dentate gyrus exhibited colocalization with NeuN (Table 1). To further substantiate this finding, additional sections from these same animals were double-labeled with antibodies to BrdU and GFAP, a glial-specific marker. BrdU-positive nuclei rarely colocalized with GFAP in the granule cell layer of the dentate gyrus, although glial cells are clearly present in the dentate and colocalization of BrdU-positive nuclei with GFAP is seen in the hilus (Table 1). With nearly all BrdU-positive nuclei in the dentate identified as differentiated neurons, the decrease in cell number subsequent to a series of recurrent seizures in the immature animal shows a decrease in the number of differentiated neurons $\sim 2$ weeks after mitotic activity. In addition, there was also a decrease in differentiated neurons in the hilus in the flurothyl-treated animals compared with controls (Table 1).

\section{A single flurothyl-induced seizure does not increase neurogenesis}

To determine whether a single seizure can also result in a change in neurogenesis, we subjected seizure-naive rats to a single flurothyl-induced seizure at P4. These rats and age-matched controls were given BrdU 24 or $48 \mathrm{hr}$ after the seizure and then killed $36 \mathrm{hr}$ or 2 weeks later. No significant difference in cell counts were obtained in either the dentate granule cell layer of the dentate gyrus or hilus when animals were killed $36 \mathrm{hr}$ after BrdU at either the 24 or $48 \mathrm{hr}$ time point ( $24 \mathrm{hr}$, dentate granule cell layer, con, $1500 \pm 74.70$; exp., $1611 \pm 108.3 ; t=0.880 ; p=$ 0.384; hilus, con., $658.7 \pm 32.79$; exp., $752.5 \pm 40.40 ; t=1.789$; $p=0.083$; $48 \mathrm{hr}$, dentate granule cell layer, con., $1222 \pm 112.6$; exp., $1324 \pm 108.7 ; t=0.640 ; p=0.5275$; hilus, con., $489.9 \pm$ 51.99; exp., 641.1 $\pm 63.11 ; t=1.736 ; p=0.094)$. Likewise, when animals were given BrdU 48 hr after the seizure and then killed 2 weeks later, no significant difference in cell counts were obtained in either the dentate granule cell layer or hilus (dentate granule cell layer, con., $811.1 \pm 54.43$; exp., $806.5 \pm 58.00 ; t=$ 0.057; $p=0.955$; hilus, con., $189.4 \pm 24.58$; exp., $194.3 \pm 17.45$; $t=0.144 ; p=0.867)$.

The number of BrdU-labeled cells 24 or $48 \mathrm{hr}$ after the single seizure or sham seizure were lower than in animals that undergone a series of seizures or sham seizures. The experimental conditions were different in the experiments. In the case of serial seizures, the animals, both those with seizures and without seizures, were handled multiple times daily, whereas with the single seizure animals, the only handling occurred at the time of the seizure or sham seizure. Although the reason for the differences 


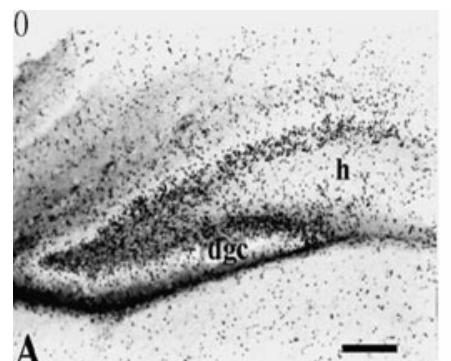

A
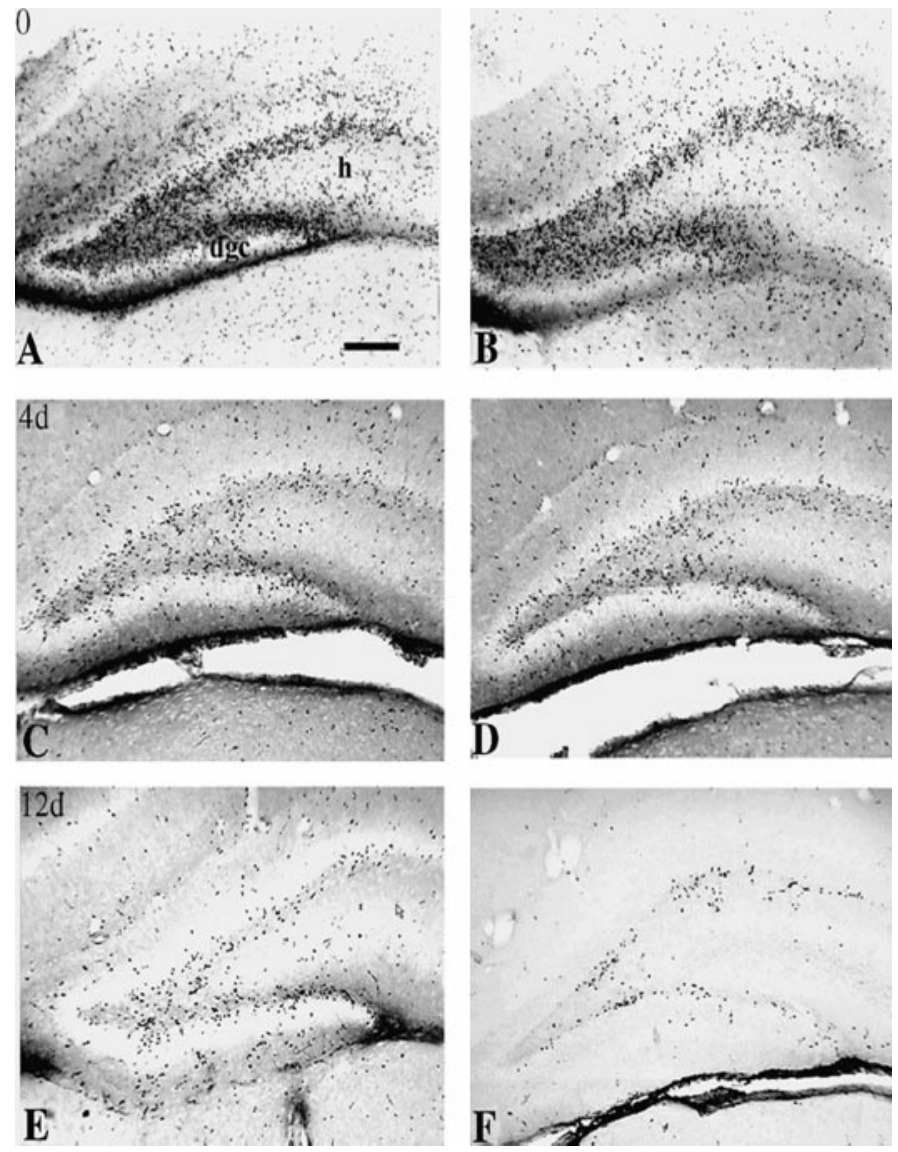

Figure 4. Examples of BrdU-labeled cells in the hours and days in controls and animals subjected to recurrent neonatal seizures. Animals were killed $36 \mathrm{hr}$ after BrdU injection. Note the general decline in the number of mitotically active cells in the controls as the animals increase in age. $A, C$, and $E$ are control animals; $B, D$, and $F$ are animals subjected to neonatal seizures. The time BrdU was administered was shortly after the 25th seizure in $A$ and $B, 4 \mathrm{~d}$ after the 25th seizures in $C$ and $D$, and $12 \mathrm{~d}$ after the 25 th seizure in $E$ and $F$. All specimens were photographed at $10 \times$. Scale bar, $100 \mu \mathrm{m}$. $d g c$, Dentate granule cell layer; $h$, hilus.

in BrdU-labeling in the two sets of experiments is not know, it is possible that neurogenesis was influenced by this stimulation.

\section{Seizure-induced decreases in neurogenesis in the immature brain begins to occur after 10 seizures}

To determine when changes in neurogenesis occur after a series of neonatal seizures, we administered BrdU after 5, 10, 15, and 20 seizures and killed the animals $36 \mathrm{hr}$ later. As can be seen in Figure 6, a decrease in neurogenesis in the granule cell layer of the dentate gyrus occurred after 10,15 , and 20 seizures but not 5 seizures. No differences in cell counts were seen in the hilus except after 10 seizures in which a decrease in hilar neurogenesis was noted.

\section{BrdU administered immediately before a seizure results in a transient increase in neurogenesis}

Because this data contrasted with earlier findings in the immature rat by Holmes et al. (1998) in which an increase in neurogenesis in the dentate granule cell layer was seen in flurothyl-treated animals, we sought to compare the short-term fate of the mitotic activity linked to seizure induction. In following Holmes et al. (1998), we modified the protocol and administered BrdU after
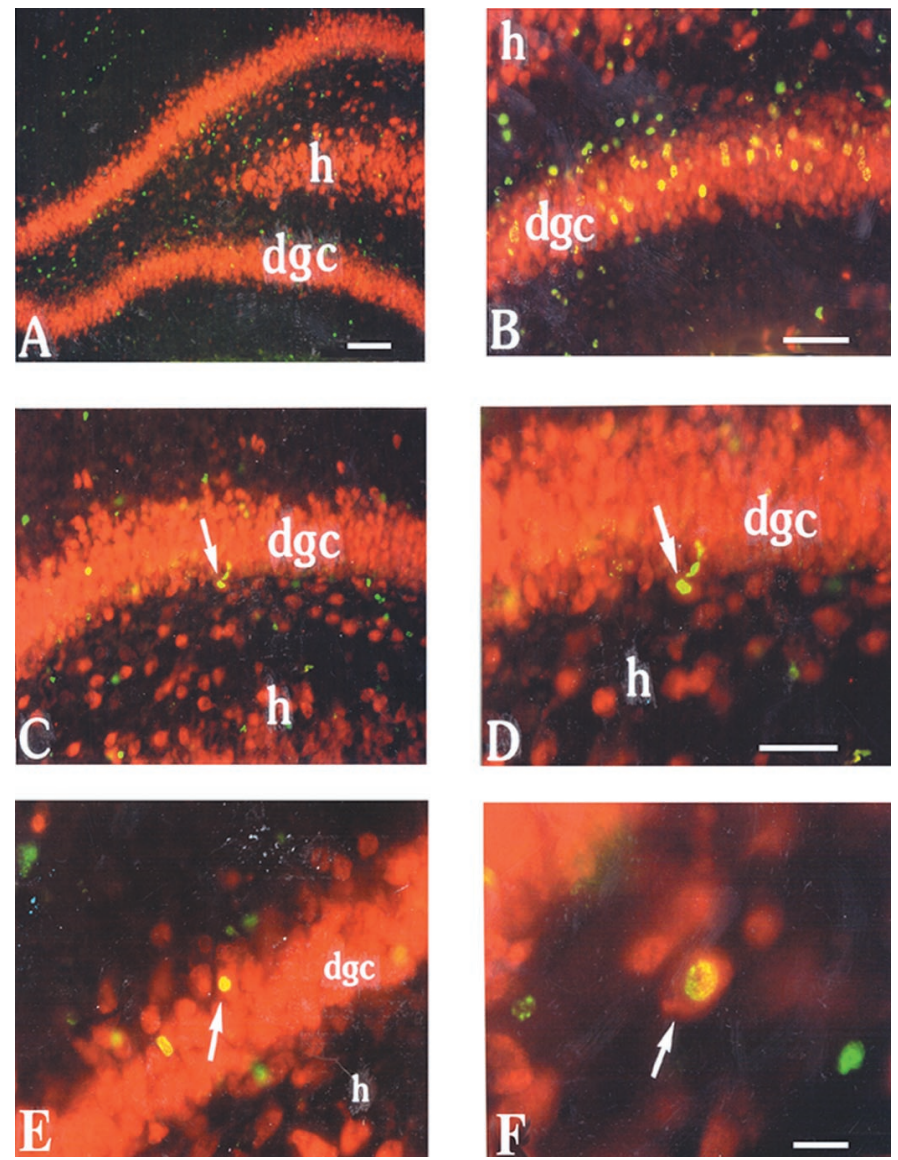

Figure 5. BrdU-positive nuclei identified as differentiated neurons by colocalization with a neuron-specific marker, NeuN. $A, B$, Animals were given systemic BrdU shortly after the 25th seizure and killed $14 \mathrm{~d}$ later. Overview $(A)$ and higher power field $(B)$ of BrdU ( green) and NeuN (red) double-labeled immunofluorescence. $C, D$, Example (arrow) of a BrdUpositive nucleus ( green) within the cytoplasmic staining of NeuN (red) at the superior blade of the dentate granule cell layer on the hilar edge (arrow). Animals had previous neonatal seizure. E, Example of BrdUlabeled cell colocalizing with NeuN at the outer edge of the superior blade of the dentate (arrow). F, Example of a BrdU-labeled cell colocalizing with NeuN in the hilus (arrow). This specimen is from a rat with neonatal seizures that was given BrdU $3 \mathrm{~d}$ after the 25th seizure and killed $14 \mathrm{~d}$ later. Specimen in $A$ was photographed at $10 \times, B$ and $C$ at $20 \times, D$ and $E$ at $40 \times$, and $F$ at $80 \times$. Scale bars: $A, 100 \mu \mathrm{m} ; B, 100 \mu \mathrm{m} ; D$, $50 \mu \mathrm{m} ; F, 20 \mu \mathrm{m}$. $d g c$, Dentate granule cell layer; $h$, hilus.

the 24th and immediately before the final (25th) seizure at P4 and then compared the number of BrdU-labeled cells at $36 \mathrm{hr}$ and $14 \mathrm{~d}$ after this labeling of mitotic activity. In the group that was killed at $36 \mathrm{hr}$ after receiving BrdU, the flurothyl-treated animals showed a significant increase in the number of mitotically active cells per square millimeters compared with the controls (con., $2205 \pm 83.94$; exp., $2646 \pm 48.11 ; p=0.009$ ). To determine whether the timing of BrdU was a determining factor in measuring neurogenesis, we also gave BrdU to rats immediately before the time of 25 th seizure but then gave the rat a sham 25 th seizure. In this situation, a decrease in neurogenesis was again noted in the experimental group (con., $2434 \pm 132.0$; exp., $1938 \pm 118.3$; $p=0.014$ ). These findings suggest that a seizure occurring during the period of time BrdU is incorporated into dividing DNA results in an increase in neurogenesis. 


\begin{tabular}{|c|c|c|c|c|c|}
\hline \multirow{2}{*}{$\begin{array}{l}\text { Time of BrdU injection } \\
\text { after the } 25 \text { th seizure }\end{array}$} & \multirow[b]{2}{*}{ Treatment } & \multicolumn{2}{|l|}{ DG } & \multicolumn{2}{|l|}{ Hilus } \\
\hline & & $\% \mathrm{BrdU}+\mathrm{NeuN}$ & $\%$ BrdU + GFAP & $\% \mathrm{BrdU}+\mathrm{NeuN}$ & $\% \mathrm{BrdU}+\mathrm{GFAP}$ \\
\hline \multirow[t]{4}{*}{$0 \mathrm{hr}$} & Con & $93.3 \pm 0.4$ & $4.9 \pm 0.4$ & $9.1 \pm 0.7^{*}$ & $82.4 \pm 2.6$ \\
\hline & Exp & $93.6 \pm 0.6$ & $5.1 \pm 0.4$ & $7.7 \pm 0.8^{*}$ & $82.2 \pm 1.1$ \\
\hline & & $\chi^{2}=0.615$ & $\chi^{2}=0.043$ & $\chi^{2}=4.209$ & $\chi^{2}=3.069$ \\
\hline & & $p=0.433$ & $p=0.835$ & $p=0.040$ & $p=0.080$ \\
\hline \multirow[t]{4}{*}{$3 \mathrm{~d}$} & Con & $93.5 \pm 0.4$ & $3.6 \pm 0.2$ & $10.5 \pm 0.6^{*}$ & $83.2 \pm 2.1$ \\
\hline & Exp & $93.3 \pm 0.7$ & $4.2 \pm 0.3$ & $7.3 \pm 0.9^{*}$ & $85.5 \pm 1.1$ \\
\hline & & $\chi^{2}=0.067$ & $\chi^{2}=2.000$ & $\chi^{2}=14.971$ & $\chi^{2}=2.663$ \\
\hline & & $p=0.795$ & $p=0.157$ & $p<0.001$ & $p=0.103$ \\
\hline \multirow[t]{4}{*}{$6 \mathrm{~d}$} & Con & $90.1 \pm 1.5$ & $8.4 \pm 1.5$ & $13.0 \pm 3.1$ & $81.0 \pm 2.3$ \\
\hline & Exp & $92.1 \pm 0.9$ & $7.2 \pm 1.7$ & $10.9 \pm 2.7$ & $86.0 \pm 2.5$ \\
\hline & & $\chi^{2}=1.031$ & $\chi^{2}=0.085$ & $\chi^{2}=0.268$ & $\chi^{2}=0.866$ \\
\hline & & $p=0.310$ & $p=0.770$ & $p=0.604$ & $p=0.352$ \\
\hline
\end{tabular}

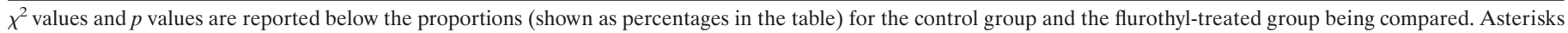
denote a significant difference between the control and experimental proportions $(p<0.05)$. Con, Control; Exp, flurothyl-treated group.

\section{Recurrent flurothyl-induced seizures in the adult animal show an increase in neurogenesis}

Because the immature brain responded differently to seizures than the adult brain did when kindled or subjected to status epilepticus (Parent et al., 1997, 1998, 1999; Scott et al., 1998), we sought to determine whether the flurothyl model of recurrent seizures has similar effects on neurogenesis in the dentate granule cell layer of the adult rat. Therefore, we examined the effect of flurothyl-induced seizures on mitotic activity in the mature (P60) rat. As seen in previous studies with other seizure models, the flurothyl model of recurrent seizures in adult animals showed an increase in neurogenesis at time points shortly after the seizure and $3 \mathrm{~d}$ after the final seizure when compared with controls (Fig. 7). This contrasts with the decreased neurogenesis seen at similar time points after the neonatal seizures.

\section{DISCUSSION}

This is the first study to systematically evaluate the effects of recurrent seizures on neurogenesis in the granule cell layer of the

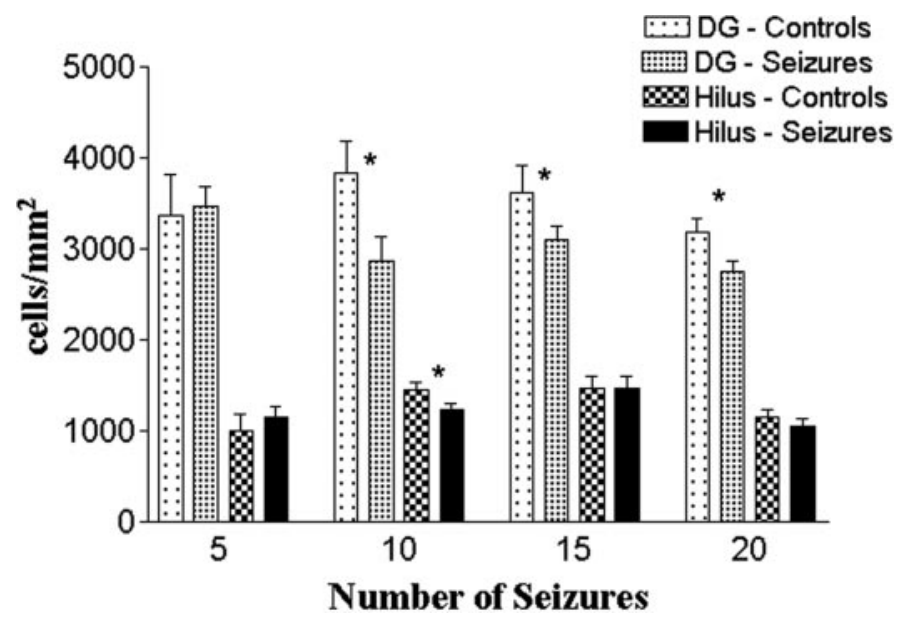

Figure 6. Comparison of differentiated BrdU-labeled cells per area (in square millimeters) (mean \pm SEM) in the rats with neonatal seizures and controls receiving BrdU immediately after $5,10,15$, or 20 seizures in the dentate gyrus and hilus in rats killed $36 \mathrm{hr}$ later. Asterisks denote statistically significant difference between seizure and control groups $\left({ }^{*} p<\right.$ $0.05)$. dentate gyrus in developing animals. The principal finding of this study was that recurrent seizures in the immediate neonatal period result in a subsequent decrease in neurogenesis in the dentate gyrus and hilus of the hippocampus. This reduction in neurogenesis persisted for days after the last seizures. These findings in the newborn rat contrast with the adult animal in which an identical number of seizures resulted in a significant increase in neurogenesis in the granule cell layer of the dentate gyrus.

\section{Recurrent neonatal seizures result in decreased dentate gyrus neurogenesis}

Dentate granule cells appear to be particularly vulnerable to postnatal insults because the majority are generated after birth. Dentate granule cells begin to originate on embryonic day 17 (E17), and by E22 the dentate gyrus is present throughout the hippocampus (Bayer, 1980). Only $\sim 20 \%$ of the granule cells are present at birth in the rat; by $\mathrm{P} 5, \sim 50 \%$ of granule cells are present. It is now well established that dentate granule cell

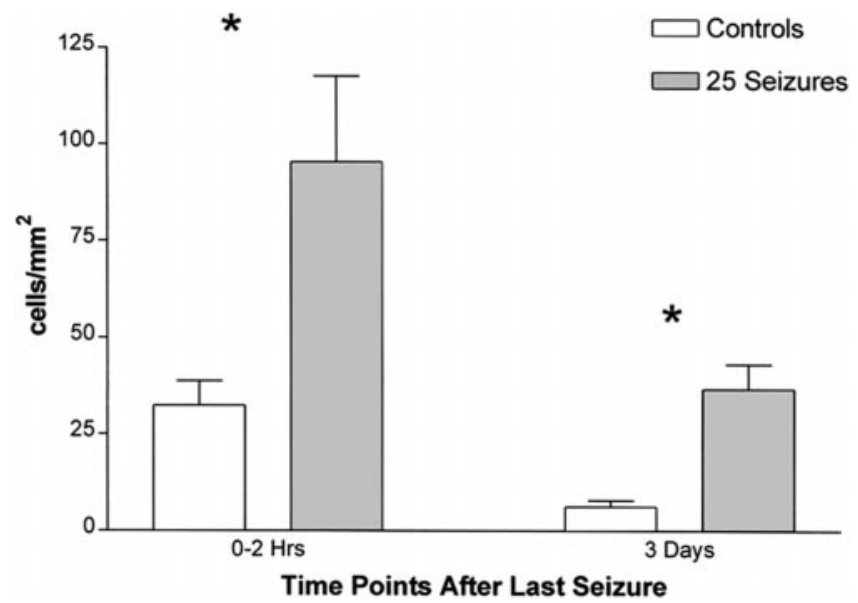

Figure 7. Adult animals show an increase in cell proliferation after a series of recurrent seizures. The flurothyl-treated animals have a statistically significant increase in the number of BrdU-labeled cells per area in the hours and days after the 25 th seizure. Adult male rats received 25 flurothyl seizures over $10 \mathrm{~d}$ or appropriate control treatment and then were given systemic BrdU either shortly after the last seizure or $3 \mathrm{~d}$ after the 25 th seizure $\left({ }^{*} p<0.05\right)$. 
neurogenesis continues into adulthood, although the rate of neurogenesis declines significantly with age of the animal (Altman and Das, 1965; Mehler and Kessler, 1999; Young et al., 1999). The progressive thickening of the granule cell layer of the dentate gyrus after birth is attributable to accumulation of neurons proliferating along its inner (hilar) margin (Angevine, 1965).

The reduction of newly formed cells in the dentate gyrus and hilus was observed shortly after the last seizure and persisted for $4 \mathrm{~d}$ after the last seizure. Through double-labeled immunofluorescence techniques, we demonstrated that the vast majority of these newly formed cells in the dentate gyrus were neurons, a finding that is consistent with other studies demonstrating that few glial cells are found in the dentate gyrus (Kosaka and Hama, 1986).

Because BrdU is available for incorporation within DNA for 30 min during the DNA-synthetic phase of the cell cycle ( $\mathrm{S}$ phase) (Packard et al., 1973), only a proportion of dividing cells will be labeled by a single injection (Nowakowski et al., 1989). However, once BrdU is incorporated into the cells, their progeny will continue to be labeled. The reduction in BrdU-labeled cells seen in our seizure-treated animals $36 \mathrm{hr}$ after the last seizures therefore is attributable to a decrease in the total number of dividing neurons during the 30 min window after at the time of BrdU injection, a subsequent reduction in the multiple divisions of proliferating progenitor cells, or increased cell death in the newly formed neurons. Although not studied here, similar studies from our laboratory using this model have failed to detect an increase in dying neurons after a series of flurothyl seizures beginning in the neonatal period (Liu et al., 1999). It is therefore likely that the reduction of BrdU-labeled neurons $36 \mathrm{hr}$ after the seizure is attributable to a reduction of neurogenesis.

When there was a 2 week delay between BrdU administration and when the rats were killed, a similar reduction of BrdU-labeled cells was again seen, suggesting that there was not a latter compensatory increase in neurogenesis. The 2 week delay in killing the animals also provided us with an opportunity to determine where these newly formed neurons eventually resided. The vast majority of cells were neurons and their final position within the dentate gyrus was similar in both groups. These findings suggest that neonatal seizures do not interfere with the migration of the granule cells to any significant degree.

We also demonstrated that, in immature rats, the decrease in neurogenesis after a series of seizures occurs relatively rapidly. Although there were no differences between neurogenesis in the controls and animals having had five flurothyl seizures, decreased neurogenesis was seen after 10, 15, and 20 seizures.

We have examined previously the effects of seizures on neurogenesis during the course of recurrent neonatal seizures (Holmes et al., 1998). When BrdU was administered immediately before a seizure, we found an increase in granule cell neurogenesis when animals were killed $36 \mathrm{hr}$ later. In that study, we identified the newly formed cells as neurons because they predominately colocalized with NeuN rather than GFAP. Because of the apparent inconsistency of those findings with the results reported here, we repeated the previous experiments and replicated the results. When BrdU was administered immediately before the seizure, we did find an increase in newly formed cells when the animals were killed $36 \mathrm{hr}$ later. However, when BrdU was administered at the same time to an animal with 24 previous seizures who then received a sham 25 th seizure, no increase in neurogenesis was noted. We interpret these findings to indicate that a seizure during the 30 min time frame when BrdU is incorporated into
DNA results in a brief period of increased neurogenesis. However, the chronic effect of recurrent seizures is a reduction in neurogenesis. Because the reduction of neurogenesis extends many days beyond the last seizure, this effect seems to be the most robust. There are other possible explanations for our findings. For example, it is conceivable that BrdU was incorporated into repairing DNA, a possibility that will require further investigation.

\section{Mechanism of seizure-induced alterations in neurogenesis}

It is known that postnatal neurogenesis can be modified by many factors. Neurogenesis in the dentate gyrus of adult rodents has been demonstrated to be modified by excitatory input and NMDA receptor activation (Cameron et al., 1995), adrenal steroids (Cameron and Gould, 1994; Gould and Tanapat, 2000) or adrenalectomy (Cameron and Gould, 1996; Montaron et al., 1999), growth factors (Cameron et al., 1998; Wagner et al., 1999), environmental stimuli (Gould et al., 1999; Young et al., 1999), running (van Praag et al., 1999a,b), estrogen (Tanapat et al., 1999), stress (Gould et al., 1998; Tanapat et al., 1998), ischemia (Liu et al., 1998), malnutrition (DeBassio et al., 1996), and seizures (Bengzon et al., 1997; Parent et al., 1997, 1998; Scott et al., 1998; Gray and Sundstrom, 1998).

The mechanism by which recurrent seizures result in reduced neurogenesis in our animals may be complex. Seizures in rat pups trigger a cascade of physiological changes, including release of glutamate (Liu et al., 1997) and corticosteroids (Baram and Schultz, 1991). Gould et al. (1994) reported that treatment of rat pups with NMDA receptor antagonists during the first postnatal week increased the density of ${ }^{3} \mathrm{H}$-thymidine-labeled cells in the dentate granule cell layer. However, blocking glutamate transmission also resulted in an increase of cell death in both ${ }^{3} \mathrm{H}$ thymidine-labeled and nonlabeled cells. The authors speculated that NMDA receptor activation serves as a signal for inhibition of both cell birth and death. Similar findings were reported in adult rats (Cameron et al., 1995). It is possible that the increased glutamate release that likely occurred during the seizures alters the balance between cell death and birth.

Previous studies have demonstrated that postnatal neurogenesis can be influenced by glucocorticoids and mineralocorticoids. Gould et al. (1991) found that administration of corticosterone or aldosterone from the second to sixth postnatal day resulted in significant decreases in the density of newly formed dentate gyrus cells. Furthermore, stress in rat pups can raise plasma corticosterone levels and diminish neurogenesis in the dentate gyrus (Tanapat et al., 1998). It is possible that the stress induced by seizures in the young animals resulted in significant rises in the steroid production leading to decreases in neurogenesis. However, stress also reduces granule cell neurogenesis in adult animals (Gould et al., 1997, 1998). If stress was a major factor in the decreased neurogenesis seen in our animals, it is not clear why a similar phenomenon would not occur in adult animals after seizures.

Another possible cause of the altered neurogenesis is hypoxia. As we demonstrated here, both the immature and adult rats became hypoxic briefly during the tonic phase of the seizure. Although the hypoxia was short in duration, seizure-induced hypoxia was induced 25 times over a $5 \mathrm{~d}$ period of time and this may have had an effect on neurogenesis. In this regard, a study by Suga and Wasterlain (1980) is of interest. The authors used methyl $\left[{ }^{3} \mathrm{H}\right]$ thymidine to label mitotic cells in the cerebellar vermis of $\mathrm{P} 4$ rats that had bicuculline-induced status epilepticus. No differences in mitotic cell number were seen 1 and $2 \mathrm{~d}$ after the 
seizure. However, $3 \mathrm{~d}$ after the seizure, a significant reduction in mitosis was noted. By $7 \mathrm{~d}$ after the seizure, the mitosis rate was similar to the controls. The authors found that severe hypoxia also reduced cerebellar vermis mitosis, although not to the extent induced by the seizure. Additional studies will be necessary to determine whether the changes we see in neurogenesis are related to hypoxia.

\section{Possible consequences of reductions in granule cell neurogenesis during development}

Using the flurothyl seizure model, we have shown previously that recurrent neonatal seizures causes sprouting of mossy fibers into the inner molecular layer of the dentate gyrus and pyramidal cell layer of CA3 in rats with neonatal seizures who were killed at P45 (Holmes et al., 1998). Unlike in the adult animal, in which sprouting appears to be closely related to cell loss (Cavazos et al., 1991), sprouting in our model of neonatal seizures was not associated with cell loss in the dentate gyrus, CA3, or CA1.

We had speculated previously that the mossy fiber sprouting seen in the flurothyl model was secondary to increased neurogenesis in the granule cell layer with subsequent excessive growth of mossy fibers into CA3 and the supragranular region of the dentate gyrus (Holmes and Ben-Ari, 1998; Holmes et al., 1998). The results of this study makes it unlikely that the seizure-induced sprouting in the immature brain is secondary to an overabundance of newly formed granule cells. Whether the decreased neurogenesis occurring at a time of mossy fiber growth results in excessive growth patterns of the axons of more mature granule cells is not known. However, in this regard, a study by Parent et al. (1999) is of interest. The authors demonstrated that reducing dentate granule cell neurogenesis with irradiation therapy after pilocarpine-induced status epilepticus in adult animals had no effect on mossy fiber synaptic reorganization, suggesting that sprouting arises from the mature granule cells.

\section{Consequences of recurrent neonatal seizures}

Our study supports the studies of Wasterlain and colleagues (Wasterlain and Plum, 1973; Wasterlain, 1976b, 1978) who concluded that recurrent neonatal seizures, although not causing cell death, resulted in reduced cell number. Wasterlain and Plum (1973) compared the effects of 10 daily electroconvulsive seizures on rats from P2-P11, P9-P18, and P19-P28. Animals receiving neonatal (P2-P11) or infantile (P9-P18) seizures had significantly smaller brains than controls. In addition, neonatal seizures reduced brain DNA, RNA, protein, and cholesterol. The authors interpreted these findings to indicate a reduction of cell number, but not cell size, in rats with neonatal seizures. To determine whether malnutrition could account for these findings, Wasterlain (1976a) repeated the studies and removed control rats from the mother for variable periods every day so that their body weight was very close to that of seizure-treated rats on each day of their life. The author found that the brains of seizure-treated rats were smaller and contained significantly fewer cells and less DNA than the brains of malnourished rats, demonstrating that malnutrition cannot explain all of the effects of seizures on brain development. Wasterlain (1976b) also found that a single, $2 \mathrm{hr}$ episode of status epilepticus induced by flurothyl in 4-d-old rats irreversibly curtailed brain weight and brain DNA. Status epilepticus inhibited DNA synthesis but did not increase DNA breakdown and produced no histological lesions. Rats with status epilepticus also showed delayed behavioral milestones and reduced seizure thresholds several weeks after status. After milder seizures, brain DNA was reduced at $7 \mathrm{~d}$ but returned to normal at $30 \mathrm{~d}$.
Although Wasterlain and colleagues (Wasterlain and Plum, 1973; Wasterlain, 1976b, 1978) convincingly demonstrated that cell number was reduced in neonatal animals with prolonged or recurrent seizures, their methods did not allow them to determine type or location of cells that were reduced. Our study expands their findings by demonstrating that recurrent neonatal seizures result in a reduction of dentate granule cell formation.

Our findings provide an additional indication that recurrent seizures during early life can have pronounced effects on brain development and that these effects are different from those occurring in the mature brain. The long-term functional consequences of our findings remain to be established but suggest that seizures can be detrimental, even in the absence of cell loss.

\section{REFERENCES}

Altman J, Bayer SA (1990) Migration and distribution of two populations of hippocampal granule cell precursors during the perinatal and postnatal period. J Comp Neurol 301:365-381.

Altman J, Das GD (1965) Autoradiographic and histological evidence of postnatal hippocampal neurogenesis in rats. J Comp Neurol 124:319-336

Angevine Jr JB (1965) Time of neuron origin in the hippocampal region. An autoradiographic study in the mouse. Exp Neurol [Suppl] 2:1-70.

Baram TZ, Schultz L (1991) Corticotropin-releasing hormone is a rapid and potent convulsant in the infant rat. Dev Brain Res 61:97-101.

Bayer SA (1980) Development of the hippocampal region in the rat. I. Neurogenesis examined with ${ }^{3} \mathrm{H}$-thymidine autoradiography. J Comp Neurol 190:87-114.

Bengzon J, Kokaia Z, Elmér E, Nanobashvili A, Kokaia M, Lindvall O (1997) Apoptosis and proliferation of dentate gyrus neurons after single and intermittent limbic seizures. Proc Natl Acad Sci USA 94:10432-10437.

Bergman I, Painter MI, Hirsch RP, Crumrine PK, David R (1983) Outcome of neonates with convulsions treated in an intensive care unit. Ann Neurol 14:642-647.

Cameron HA, Gould E (1994) Adult neurogenesis is regulated by adrenal steroids in the dentate gyrus. Neuroscience 61:203-209.

Cameron HA, Gould E (1996) Distinct populations of cells in the adult dentate gyrus undergo mitosis or apoptosis in response to adrenalectomy. J Comp Neurol 369:56-63.

Cameron HA, McEwen BS, Gould E (1995) Regulation of adult neurogenesis by excitatory input and NMDA receptor activation in the dentate gyrus. J Neurosci 15:4687-4692.

Cameron HA, Hazel TG, McKay RDG (1998) Regulation of neurogenesis by growth factors and neurotransmitters. J Neurobiol 36:287-306.

Cavazos JE, Golarai G, Sutula TP (1991) Mossy fiber synaptic reorganization induced by kindling: time course of development, progression, and permanence. J Neurosci 11:2795-2803.

Chen K, Baram TZ, Soltesz I (1999) Febrile seizures in the immature rat model modify neuronal excitability long-term. Nat Med 5:888-894.

DeBassio WA, Kemper TL, Tonkiss J, Galler JR (1996) Effect of prenatal protein deprivation on postnatal granule cell generation in the hippocampal dentate gyrus. Brain Res Bull 41:379-383.

del Rio JA, Soriano E (1989) Immunocytochemical detection of 5'bromodeoxyuridine incorporation in the central nervous system of the mouse. Dev Brain Res 49:311-317.

Gould E, Tanapat P (2000) Stress and hippocampal neurogenesis. Biol Psychiatry 46:1472-1479.

Gould E, Woolley CS, Cameron HA, Daniels DC, McEwen BS (1991) Adrenal steroids regulate postnatal development of the rat dentate gyrus. II. Effects of glucocorticoids and mineralocorticoids on cell birth. J Comp Neurol 314:486-493.

Gould E, Cameron HA, McEwen BS (1994) Blockade of NMDA receptors increases cell death and birth in the developing rat dentate gyrus. J Comp Neurol 340:551-565.

Gould E, McEwen BS, Tanapat P, Galea LAM, Fuchs E (1997) Neurogenesis in the dentate gyrus of the adult tree shrew is regulated by psychosocial stress and NMDA receptor activation. J Neurosci 17:2492-2498.

Gould E, Tanapat P, McEwen BS, Flugge G, Fuchs E (1998) Proliferation of granule cell precursors in the dentate gyrus of adult monkeys is diminished by stress. Proc Natl Acad Sci USA 95:3168-3171.

Gould E, Beylin A, Tanapat P, Reeves A, Shors TJ (1999) Learning enhances adult neurogenesis in the hippocampal formation. Nat Neurosci 2:260-265.

Gray WP, Sundstrom LE (1998) Kainic acid increases the proliferation of granule cell progenitors in the dentate gyrus of the adult rat. Brain Res 790:52-59. 
Holmes GL, Ben-Ari Y (1998) Seizures in the developing brain: perhaps not so benign after all. Neuron 21:1231-1234.

Holmes GL, Gaiarsa JL, Chevassus-Au-Louis N, Ben-Ari Y (1998) Consequences of neonatal seizures in the rat: morphological and behavioral effects. Ann Neurol 44:845-857.

Holmes GL, Sarkisian M, Ben-Ari Y, Chevassus-Au-Louis N (1999) Mossy fiber sprouting following recurrent seizures during early development in rats. J Comp Neurol 404:537-553.

Kosaka T, Hama K (1986) Three-dimensional structure of astrocytes in the rat dentate gyrus. J Comp Neurol 249:242-260.

Lanska MJ, Lanska DJ, Baumann RJ, Kryscio RJ (1995) A populationbased study of neonatal seizures in Fayette County, Kentucky. Neurology 45:724-732.

Liu J, Solway K, Messing RO, Sharp FR (1998) Increased neurogenesis in the dentate gyrus after transient global ischemia in gerbils. J Neurosci 18:7768-7778.

Liu Z, Stafstrom CE, Sarkisian MR, Yang Y, Hori A, Tandon P, Holmes GL (1997) Seizure-induced glutamate release in mature and immature animals: an in vivo microdialysis study. NeuroReport 8:2019-2023.

Liu Z, Yang Y, Silveira DC, Sarkisian MR, Tandon P, Huang LT, Stafstrom CE, Holmes GL (1999) Consequences of recurrent seizures during early brain development. Neuroscience 92:1443-1454.

Mehler MF, Kessler JA (1999) Progenitor cell biology. Implications for neural regeneration. Arch Neurol 56:780-784.

Meldrum BS, Vigouroux RA, Brierley JB (1973) Systemic factors and epileptic brain damage. Prolonged seizures in paralysed artificially ventilated baboons. Arch Neurol 29:82-87.

Mizrahi EM, Plouin P, Kellaway P (1997) Neonatal seizures. In: Epilepsy: a comprehensive textbook (Engel Jr J, Pedley TA, eds), pp 647-663. Philadelphia: Lippincott-Raven.

Montaron MF, Petry KG, Rodriguez JJ, Marinelli M, Aurousseau C, Rougon G, Le Moal M, Abrous DN (1999) Adrenalectomy increases neurogenesis but not PSA-NCAM expression in aged dentate gyrus. Eur J Neurosci 11:1479-1485.

Nadler JV (1981) Kainic acid as a tool for the study of temporal lobe epilepsy. Life Sci 29:2031-2042.

Nadler JV, Perry BW, Cotman CW (1978) Intraventricular kainic acid preferentially destroys hippocampal pyramidal cells. Nature 271: 676-677.

Neill J, Liu Z, Sarkisian M, Tandon P, Yang Y, Stafstrom CE, Holmes GL (1996) Recurrent seizures in immature rats: effect on auditory and visual discrimination. Dev Brain Res 95:283-292.

Nowakowski RS, Lewin SB, Miller MW (1989) Bromodeoxyuridine immunohistochemical determinations of the lengths of cell cycle and the DNA-synthetic phase for an anatomically defined population. J Neurocytol 18:311-318.

Okazaki ME, Evenson DA, Nadler JV (1995) Hippocampal mossy fiber sprouting and synapse formation after status epilepticus in rats: visualization after retrograde transport of biocytin. J Comp Neurol 352:515-534.

Packard Jr DS, Menzies RA, Skalko RG (1973) Incorporation of thymidine and its analogue, bromodeoxyuridine, into embryos and maternal tissues of the mouse. Differentiation 1:397-405.

Painter MJ, Bergman I, Crumrine P (1986) Neonatal seizures. Pediatr Clin North Am 33:91-109.

Parent JM, Yu TW, Leibowitz RT, Geschwind DH, Sloviter RS, Lowenstein DH (1997) Dentate granule cell neurogenesis is increased by seizures and contributes to aberrant network plasticity in the adult hippocampus. J Neurosci 17:3727-3738.

Parent JM, Janumpalli S, McNamara JO, Lowenstein DH (1998) Increased dentate granule cell neurogenesis following amygdala kindling in the adult rat. Neurosci Lett 247:9-12.

Parent JM, Tada E, Fike JR, Lowenstein DH (1999) Inhibition of den- tate granule cell neurogenesis with brain irradiation does not prevent seizure-induced mossy fiber synaptic reorganization in the rat. J Neurosci 19:4508-4519.

Represa A, Tremblay E, Ben-Ari Y (1987) Kainate binding sites in the hippocampal mossy fibers: localization and plasticity. Neuroscience 20:739-748.

Sankar R, Shin DH, Liu H, Mazarati A, Pereira de Vasconcelos A, Wasterlain CG (1998) Patterns of status epilepticus-induced neuronal injury during development and long-term consequences. J Neurosci 18:8382-8393.

Sankar R, Shin D, Mazarati AM, Liu H, Katsumori H, Lezama R, Wasterlain CG (2000) Epileptogenesis after status epilepticus reflects age- and model-dependent plasticity. Ann Neurol 48:580-589.

Schlessinger AR, Cowan WM, Gottlieb DI (1975) An autoradiographic study of the time of origin and the pattern of granule cell migration in the dentate gyrus of the rat. J Comp Neurol 159:159-176.

Scott BW, Wang S, Burnham WM, De Boni U, Wojtowicz JM (1998) Kindling-induced neurogenesis in the dentate gyrus of the rat. Neurosci Lett 248:73-76.

Soriano E, del Rio JA (1991) Simultaneous immunocytochemical visualization of bromodeoxyuridine and neural tissue antigens. J Histochem Cytochem 39:255-263.

Sperber EF, Haas KZ, Stanton PK, Moshé SL (1991) Resistance of the immature hippocampus to seizure-induced synaptic reorganization. Dev Brain Res 60:88-93.

Stafstrom CE, Thompson JL, Holmes GL (1992) Kainic acid seizures in the developing brain: status epilepticus and spontaneous recurrent seizures. Dev Brain Res 65:227-236.

Stafstrom CE, Chronopoulos A, Thurber S, Thompson JL, Holmes GL (1993) Age-dependent cognitive and behavioral deficits following kainic acid-induced seizures. Epilepsia 34:420-432.

Suga S, Wasterlain CG (1980) Effects of neonatal seizures or anoxia on cerebellar mitotic activity in the rat. Exp Neurol 67:573-580.

Tanapat P, Galea LA, Gould E (1998) Stress inhibits the proliferation of granule cell precursors in the developing dentate gyrus. Int J Dev Neurosci 16:235-239.

Tanapat P, Hastings NB, Gould E (1999) Estrogen stimulates a transient increase in the number of new neurons in the dentate gyrus of the adult female rat. J Neurosci 19:5792-5801.

Toth Z, Yan XX, Haftoglou S, Ribak CE, Baram TZ (1998) Seizureinduced neuronal injury: vulnerability to febrile seizures in an immature rat model. J Neurosci 18:4285-4294.

van Praag H, Christie BR, Sejnowski TJ, Gage FH (1999a) Running enhances neurogenesis, learning, and long-term potentiation in mice. Proc Natl Acad Sci USA 96:13427-13431.

van Praag H, Kempermann G, Gage FH (1999b) Running increases cell proliferation and neurogenesis in the adult mouse dentate gyrus. Nat Neurosci 2:266-270

Wagner JP, Black IB, DiCicco-Bloom E (1999) Stimulation of neonatal and adult brain neurogenesis by subcutaneous injection of basic fibroblast growth hormone. J Neurosci 19:6006-6016.

Wasterlain CG (1976a) Developmental effects of seizures: role of malnutrition. Pediatrics 57:197-200.

Wasterlain CG (1976b) Effects of neonatal status epilepticus on rat brain development. Neurology 26:975-986.

Wasterlain CG (1978) Neonatal seizures and brain growth. Neuropaediatrie 9:213-228.

Wasterlain CG, Plum F (1973) Vulnerability of developing rat brain to electroconvulsive seizures. Arch Neurol 29:38-45.

Young D, Lawlor PA, Leone P, Dragunow M, During MJ (1999) Environmental enrichment inhibits spontaneous apoptosis, prevents seizures and is neuroprotective. Nat Med 4:448-453. 